\title{
TEXTUALISM AND SCEPTICISM: POST-MODERN PHILOSOPHY AND THE THEOLOGY OF TEXT
}

\author{
Federico Dal Bo*
}

\begin{abstract}
This paper addresses the religious notion of "textualism" - the formalistic assumption that a text is meaningful only when it is understood in itself and solely from itself. In the present paper, I will implicitly refer to this legal notion of "textualism" but I will be more generic with respect to the interpretation of the text and more specific with respect of the nature of the text itself. On the one hand, I will refer to "textualism" as to the hermeneutical assumption that the meaning of a text is inherently autonomous and does not require extra-textual sources; on the other hand, I will specifically refer here to religious texts and assume that they shall not be understood outside from their inherent cultural perimeter.
\end{abstract}

This paper addresses the religious notion of "textualism" - the formalistic assumption that a text is meaningful only when it is understood in itself and solely from itself. More specifically, the notion of "textualism" has been introduced in contemporary jurisprudence in order to justify interpretations of legal texts under the presupposition that their ordinary meaning - eventually provided both by their rhetoric and their legal vocabulary - should govern their exhaustive interpretation. This assumption obviously has a clear consequence: non-textual sources would necessarily escape the intention of the legislator and therefore shall be excluded from ordinary hermeneutical means by which to interpret the legal texts themselves. ${ }^{1}$

In the present paper, I will implicitly refer to this legal notion of "textualism" but I will be more generic with respect to the interpretation of the text and more specific with respect of the nature of the text itself. On the one hand, I will refer to "textualism" as to the hermeneutical assumption that the meaning of a text is inherently autonomous and does not require extra-textual sources; on the other hand, I will specifically refer here to religious texts and assume that they shall not be understood outside from their inherent cultural perimeter. In the present paper I will refrain from treating the notion of "textualism" within Scripture itself, since this would rather require a specific treatment of a number of unavoidable very complex issues, such as: the definition of Biblical canon and the distinction between Jewish, Catholic, Christian-Orthodox, and Protestant Biblical canon; ${ }^{2}$ the difference and battle for supremacy between different Biblical languages

\footnotetext{
*Post-doctoral fellow at the ICI Berlin Institute for Cultural Inquiry. Email: fdalbo@gmail.com

1 On a critical appreciation of the notion of "textualism" as a doctrine about statutory interpretation applied especially to the Anglo-Saxon Common Law, see: Andrei Marmor, Law in the Age of Pluralism (Oxford: Oxford University Press, 2007), 197-214. For a philosophical definition of "textualism," see: Richard Rorty, "NineteenthCentury Idealism and Twentieth-Century Textualism," The Monist 64.2 (1981): 155-174, published also in Richard Rorty, Consequences of Pragmatism. Essays, 1972-1980 (Minneapolis: University of Minnesota Press, 1982): 139-159.

2 On this, see for instance, the recent: Lee Martin McDonald, The Biblical Canon. Its Origin, Transmission, and Authority (Minneapolis: University of Minnesota Press, 2006); see also: Lee Martin McDonald, The Canon Debate, ed. James A. Sanders (Massachusetts: Hendrickson Publishers, 2002).
} 
(Hebrew, Aramaic, Greek, Syriac, and Latin); ${ }^{3}$ finally, the definition of Jewish Biblical canon with respect to the vocalization of the Hebrew Scripture. ${ }^{4}$

Therefore, I will assume as self-evident that Scripture represents the fundamental horizon for any Jewish definition of "textualism" and I will distinguish between four different notions in Rabbinic literature in particular and in Judaism in general. More specifically I will assume that each of these kinds of "textualism" involves a specific appreciation of the interpreter's mind, the modes of interpretation, and the epistemological result of investigating a text. 5 These four notions of "textualism" are:

1. the Rabbinic notion of "Scripture,"

2. the Midrashic notion of "Scripture,"

3. the Kabbalistic notion of "Scripture,"

4. the post-modern philosophical notion of "Text."

My working thesis is that the Rabbinic notion of "Scripture" has developed in parallel both chronologically and conceptually - to a Midrashic and a Kabbalistic notion of "Scripture" since the assumption of "Scripture" as the fundamental text of Judaism. As far as it is problematic to provide a generic definition of each of these kinds of Jewish "textualism," I would assume the following: a Rabbinic notion of "Scripture" assumes Scripture as the ultimate gnoseological - that is: cognitive - horizon; a Midrashic notion of "Scripture" assumes Scripture as the ultimate cosmological horizon; a Kabbalistic notion of "Scripture" assumes Scripture as the ultimate ontological horizon; conversely, postmodern philosophy - both in Marc-Alain Ouaknin, ${ }^{6}$ Jacques Derrida, ${ }^{7}$ and Catherine $\mathrm{Malabou}^{8}$ - tends to refrain from directly addressing Scripture, assumes rather the horizon

\footnotetext{
${ }^{3}$ On linguistic tensions and struggle for predomination, see: Louis-Jean Calvet, Language Wars and Linguistic Politics (Oxford: Oxford University Press, 1998).

${ }^{4}$ On this topic see: Emanuel Tov, Textual Criticism of the Hebrew Bible (Minneapolis: Fortress Press, 1992); see also: Stefen Schorch, "Rewritten Bible and the Vocalization of the Biblical Text," in Rewritten Bible after Fifty Years. Text, Terms, or Techniques, ed. J. Zsengellér (Leiden: Brill, 2014): 137-152.

${ }^{5}$ Here and in the next pages I follow: Moshe Idel, Absorbing Perfection. Kabbalah and Interpretation (New Haven: Yale University Press, 2002).

${ }^{6}$ Marc-Alain Ouaknin (1957) is a prominent French rabbi and a philosopher, especially famous for his best-known work Le livre brûlé, Lire le Talmud (Paris: Lieu Commun, 1986 and Paris: Éditions du Seuil, 1992) in which he elaborated on the Gentile animosity to the Talmud and interprets its "burning" also in light of an unwitting act of complicity as a self-indulgent practise of "self-effacement." On his work, see: Martin Kavka, "Saying Nihilism: A Review of Marc-Alain Ouaknin's 'Burnt Book," in Shaul Magid (ed), God's Voice from the Void (Albany: State University of New York, 2002): 217-236.

${ }^{7}$ Jacques Derrida (1930-2004) was one of the most representative figures in post-war French philosophy. His work is universally associated with the notion of "deconstruction" - a specific form of semiotic analysis that he developed from the Heideggerian notion of "destruction of metaphysics." Derrida progressively abandoned his initial post-phenomenological orientation, prominent in his first works, for a more post-hermeneutical one, usual in his later works and influenced by the American hermeneutical school (the so called "Yale Critics"). Scholarship on him is immense. See: Albert Leventure, "A Bibliography of the French and English Works of Jacques Derrida, 196290," Textual Practice 5, no. 1 (1991). William R. Schultz, Jacques Derrida: an Annotated Primary and Secondary Bibliography (New York: Garland, 1992); Mano Daniel, "A Bibliography of Derrida and Phenomenology," in Derrida and Phenomenology, eds. William R. McKenna and J. Claude Evans (Dodrecht: Springer, 1995), 201-211; Peter Zellinger, Jacques Derrida: Bibliographie der Französischen, Deutschen und Englischen Werke (Wien: Turia \& Kant, 2005); Gidon Ofrat, ha-Berit ye-ha-milah shel Z'ak Deridah: 'al Yahadut ke-Petsa', ke-Hotam u-khe-Aherut (Tel Aviv: ha-Kibutz haMeuhad, 2008); Michael Fisch, Jacques Derrida: Bibliographie der Deutschsprachigen Veröffentlichungen in Chronologischer Folge, Geordnet nach den Französischen Erstpublikationen, Erstvorträgen oder Erstabdrucken von 1959 bis 2009 (Berlin: Weidler, 2011).

${ }^{8}$ Catherine Malabou (1959) is a UK-based French philosopher who has developed the notion of "plasticity" with respect of the Hegelian notion of "future" (avenir), by combining elements from both continental philosophy and modern neuro-sciences, in resonance with Giorgio Agamben's notion of "bare life" (nuda vita). For a short sample of
} 
of "secularization," usually conforming to Carl Schmitt's philosophy of law, ${ }^{9}$ and inclines for "a kind of atheism," as he emphasized on textuality and plurivocality - that is: the unavoidable, disseminating openness to "many voices," in contrast with the towering, normative "single voice" of the text. ${ }^{10}$ As a consequence of this, post-modern philosophy exhibits scepticism as well as a certain residue of Kabbalistic thought in their "cult" of the book or textuality - probably developing into what Eco has called: "atheistic mystics." 11

\section{The Rabbinic notion of "Scripture"}

The Rabbinic notion of "Scripture" designates a textual universe in which everything is essential and autonomous - especially from an epistemological and legal point of view. This notion is exemplified in a famous statement from the Mishnah, specifically from the later tractate Avot:

Ben Bag Bag said: Turn it [the Torah] over and over, since everything is in it. Look into it, grow old and worn over it, and never move away from it, for you will find no better portion than it. (mAvot 5:26)

The meaning of this famous dictum is at first quite obvious - Scripture is the ultimate, both existential and scientific for a pious Jewish man, who should never keep away from learning it every moment of his life. In the present context I want to emphasize the anomalous nature of tractate Avot. As some scholars maintain, tractate Avot would be an "addition" to the final redaction of the Mishnah and would play a substantial "ideological" role - emphasizing the importance of the Pharisaic law over any other secular discipline. With respect to this, the Rabbinic notion of "Scripture" would essentially pertain to the epistemological prominence of Scripture over other concurrent disciplines. As such, it would not claim for any specific ontological value of Scripture in strict sense.

More specifically, the dictum of Ben Bag Bag about the pervasive nature of Scripture should be interpreted in association with other two important assumptions of tractate Avot:

her work, see the following short article on Jewish Studies: Catherine Malabou, "La Compulsion de Révélation," Judéités, 2003: 205-217.

${ }^{9}$ See: Carl Schmitt, The Concept of the Political (Chicago: University of Chicago Press, 1996). Carl Schmitt (18881985) was a prominent German jurist and politician, who mostly worked on political theory, legal theory, and continental philosophy. Despite his affiliation with National Socialism, Schmitt's works - together with his core concepts, such as the notion of "political," the notion of "dictatorship," and the "enemy-friend" distinction - have been extremely influential on modern continental philosophy and have been variously received by both left-wing and right-wing intellectuals (for example, Walter Benjamin, Leo Strauss, Jürgen Habermas, and Giorgio Agamben). For a recent introduction to his philosophy of law, see: Mariano Croce and Andrea Salvatore, The Legal Theory of Carl Schmitt (London: Routledge, 2013).

${ }^{10}$ The notion of "plurivocality" is particularly disseminated in deconstruction and designates the fundamental assumption that every text is more or less implicitly carved out from "inner voices" to which traditional hermeneutics intends to oppose a single, leading "voice" that also salvages from the mutism of the text. For the assumption that Platonic dialogues, for instance, may be interpreted as "monologues," see my article: Federico Dal Bo, "Il Teatro del Sapere. Una Interpretazione della Repubblica Platonica," Philo-Logica 5, no. 9 (1996): 91-104. For a use of "plurivocality" in Jewish theology, see: Elliot Wolfson, Giving Beyond the Gift. Apophasis and Overcoming Theomania (New York: Fordham University Press, 2014).

${ }^{11}$ Umberto Eco, Semiotics and the Philosophy of Language (Bloomington: Indiana University Press, 1984): 156. 
i. that the Oral Law had been transmitted by Moses on the Sinai though several generations of scholars,

ii. and that the obvious juridical nature of the Oral Law has an intrinsic moral nature, as maintained in many Rabbinic dicta reported in this tractate.

These remarks are important in order to fully appreciate this Rabbinic notion of "textualism." On the one hand, Scripture is described as the ultimate hermeneutical and existential horizon; on the other hand, this prominent role is justified both by traditional and moral reasons. This would bring us to conclude that the Rabbinic-Talmudic notion of "Scripture" claims for the divine origin of the Bible, for its intrinsic moral qualities, and for its encyclopaedic character, without implying that God actually is in the text in the strictest sense of the expression. Indeed, this will be the characteristic trait in Midrashic and Kabbalistic thought.

\section{The Midrashic notion of "Scripture"}

The Midrashic notion of "Scripture" is strongly dependent on the former Rabbinic notion of "Scripture" but it introduces a fundamental addition to it: "Scripture" would be not only the epistemological but also the ultimate cosmological horizon. This notion is well exemplified in a famous midrash that speaks about the connection between Creation and Scripture:

Rabbi Jonah said in Rabbi Levi's name: Why was the world created with a beth? Just as the beth is closed at the sides but open in front, so you are not permitted to investigate what is above and what is below, what is before and what is behind (Bereshit Rabbah I:10.1)

The assumption of the commentator is that there is an intrinsic connection between the letters of Scripture and Creation itself. Yet this congruence does not necessarily imply a "pan-textual" vision of reality: that is, the assumption that God actually dwells in within the text. The assumption that the Hebrew letters and the universe converge into a single discrete reality - the letters themselves - anticipates many later, more radical assumptions that textualism provides an ontological horizon but shall be interpreted, at this point, as the generic acknowledgment that Scripture and Creation are interconnected.

This interconnection is particularly evident in the pre-kabbalistic Sefer Yetzirah that describes the Hebrew letters as "potencies" from which the universe has been created:

By means of thirty-two wondrous paths of wisdom Yah, the Lord of hosts, the God of Israel, the Living God, God Almighty, high and exalted, dwelling forever, and holy is his name, carved out. He created this universe with three groups of letters (sefarim), with sefer, sefer, and sefer (Sefer Yetzirah 1:1)

The impact of the Sefer Yetzirah on the later layers of Judaism is almost incommensurable but one could easily distinguish between three different approaches: a magical, a 
philosophical, and a theosophical one. In her recent survey on the Sefer Yetzirah, Marla Segol has successfully demonstrated that there was a difference when not a rivalry between a magical, philosophical, and theosophical understanding of the Sefer Yetzirah. ${ }^{12}$ Each of these different kinds of interpretation of the text does not simply involve the content of the text - or of a passage like the one quoted above - but also and especially a different attitude toward symbols.

Firstly, magic commentaries on the Sefer Yetzirah tended to posit a direct relationship between letters and universe on account of an implicit onomatology (or "science of the divine names"): just as the divine names - as transmitted in Scripture - are active in creation, so have their letters and, by extension, any Hebrew letter part of it. Secondly, philosophical commentaries on the Sefer Yetzirah did not reject the speculative tension between an immanent and transcendent God but usually tended to assume that the Hebrew letters and, by extension, the "text" of Scripture itself were to be understood as divine powers that are not created from the divine substance and therefore are not ontologically - either immanently or transcendently - related to it. Finally, theosophical commentaries on the Sefer Yetzirah projected the cosmological connection between the Hebrew letters and the universe into an ontological perspective, so that the symbolic dimension would intersect when not overlap with the divine dimension. It is especially this latter approach - as anticipated - that this cosmological assumption turns into an evident ontological one.

\section{The Kabbalistic notion of "Scripture"}

The Kabbalistic notion of "Scripture" is fundamentally derived on the gnoseological Rabbinic and cosmological Midrashic assumptions with an important addition: Scripture would be the ultimate ontological horizon of reality - in which God Himself is to be found.

This Kabbalistic notion of "textualism" - usually predating pre-existing philosophies of languages and pre-Kabbalistic speculations on the divine names - fundamentally assumes that the divine name known as the Tetragrammaton serves as the very foundation of reality and the Hebrew language that are therefore coincidental from a formal point of view and yet diverse from a epistemological and cosmological point of view. As far as the Hebrew language is able to provide the fundamental elements of the divine and mundane reality, there is still an evident difference between them: therefore a Kabbalistic philosophy of language and its "textualism" usually involve also collateral disciplines such as epistemology and cosmology - by which to come to terms with the actual differences between the divine and mundane reality or, in other words, between God and the world. In this perspective, it is obvious that a Kabbalistic notion of "textualism" has a particular prominence only within a more complex realm of mystical disciplines that then involve collateral activities, such as: magic, theurgy, cosmology, prayers and so on. Only for brevity's sake, will the Kabbalistic notion of "textualism" be treated in the present occasion as if it were the only speculative dimension that interested the followers of Jewish

12 Marla Segol, Word and Image in Medieval Kabbalah. The Texts, Commentaries, and Diagrams of the Sefer Yetsirah (Hampshire: Palsgrave McMillan, 2012), 34. 
mysticism. In this perspective, "textualism" designates the ultimate ontological horizon without which there could be neither letters nor words, neither language nor reality.

This generic notion of "textualism" has several variants according to the Kabbalistic school to which it is associated: prophetic, practical, and theosophical Kabbalah. ${ }^{13}$

In the present occasion I will focus on a particular one of these streams of the Kabbalah: the theosophical Kabbalah - elaborated by the $13^{\text {th }}$ century kabbalist Yosef ben Abraham Gikatilla ${ }^{14}$ who is commonly associated with Moshe de Leon and his redaction of the Zohar. ${ }^{15}$ Yosef ben Abraham Gikatilla has gained prominence in Jewish mysticism from his detailed investigations into the secrets of the names of God. Indeed, his commentaries on the ten sefirot were largely read in the past and are considered still now some of the best introductions to Jewish mysticism. In his later introduction to the doctrine of the divine names, Gikatilla elaborates on the assumption that Scripture is a whole name of God (as maintained by the school of Gerona) ${ }^{16}$ and associates every apex of every letter of Scripture to the Infinite, the En Sof that transcends every physical and supernal manifestation of reality.

Gikatilla maintains then that every letter of Scripture is fundamentally connected to God due to a specific linguistic-ontological relationship. Gikatilla wrote Sha'arey Tzedek ("The Gates of Justice") under the implicit assumption that specific "secrets" of God's names can be revealed in written form but that only very few might be able to grasp their significance of God's supreme name. Gikatilla maintains this sense for exclusiveness in a very subtle way:

The supernal secret of the apex of the letter Yod is the secret of Crown in the name that is called Ehyeh that is called nothing from nothing. In the apex Crown is united with the rest of the surnames. Therefore, you find that this Name, which is Yhwh, includes all the ten sefirot in four letters in all the holy names in the divine Law" (Sha'arey Tzedek 57r-v).

\footnotetext{
${ }^{13}$ For this canonical distinction, see: Moshe Idel, Kabbalah. New Perspectives (New Haven: Yale University Press, 1990).

${ }^{14}$ Rabbi Joseph ben Abraham Gikatilla (1248 - c. 1325) is considered the most representative figure of a stream of kabbalah devoted in particular to the investigation of the mysteries of the divine names. Despite his fame, information about the life of Gikatilla is sparse. Apparently, he was born in the Castilian city of Medinaceli (called also Medinat Celim and Medinat Shalom in Hebrew sources). There, he might have been educated in the kabalistic speculation of Abraham Abulafia (1240 - c. 1292) and seems to have written most of his works. Cf. Shlomo Blickstein, Between Philosophy and Mysticism: a Study of the Philosophical-Qabbalistic Writings of Yosef Gikatila (PhD thesis, New York, 1983), 1-2, n. 1 and 149-150; Gershom Scholem, Kabbalah (New York: Dorset Press, 1987), 409-411.

${ }^{15}$ Rabbi Moshe de Leon (1240-1305) was a leading figure in the $13^{\text {th }}$ century Kabbalah in Spain, whom Gershom Scholem considered to be the "author" of the Zohar, the main work of Jewish mysticism, which traditional religious scholarship pseudo-epigraphically attributes to Rabbi Shimon bar Yochai, a Tannaitic master of first- and secondcentury Judaism. Modern scholarship has partially revised Scholem's assumptions and especially his supposition that Moshe de Leon wrote his Hebrew texts after writing in Aramaic his main work - the Zohar. It is now assumed that Moshe de Leon wrote the Zohar in Aramaic both by translating his Hebrew texts into Aramaic and by exchanging ideas and concepts with his Spanish colleagues. For a recent investigation on the development of the Zohar, see: Daniel Abrams, "The Invention of the Zohar as a Book: On the Assumptions and Expectations of the Kabbalists and Modern Scholars," Kabbalah: Journal for the Study of Jewish Mystical Texts 19, 2009: 7-142; Daniel Abrams, Kabbalistic Manuscripts and Textual Theory. Methodologies of Textual Scholarship and Editorial Practices in the Study of Jewish Mysticism (Jerusalem: Magnes Press, 2016).

${ }^{16}$ The so called "School of Gerona" is the collective name for a group of Spanish kabbalistis who were particularly active between the twelfth and thirteenth centuries in the Spanish city of Gerona, in Catalona: Rabbi Isaac the Blind (1160-1235), Rabbi Ezra ben Solomon (dead in 1238 or 1245), and Rabbi Azriel ben Menachem (1160-1238). On this, see the classic: Gershom Scholem, Origins of the Kabbalah (Princeton: Princeton University Press, 1990), 365-495.
} 
Gikatilla apparently began to revise Sha'arey Tzedek and he wrote also a longer final chapter - published by Ephraim Gottlieb in $1970 .{ }^{17}$ In this new chapter, Gikatilla cautiously offers a more moderate approach to the notion of "textualism." On the one hand, Gikatilla implicitly accepts the former limitations imposed to the Patriarchs Abraham and Isaac and, by implication, to Islam and Christianity. On the other hand, Gikatilla seems to extend someone's ability to access to the secret of the Supreme Name. In the revised last chapter of Sha'arey Tzedek, Gikatilla actually maintains that it is possible to access Crown not only through the apex of the single letter Yod of the Tetragrammaton but also through every apex of every letter in Scripture:

on the secret of this Crown are attached all the intimate secretes of the apexes of the letters in the divine Law. All the crowns [of the letters] are all hinted and attached in the Crown. The apexes and the crowns [of the letters] show that the divine Law has no end and that there are no boundaries in Wisdom from the side of the supreme Crown (Last chapter of Sha'arey Tzedek, 46b, ed. Gottlieb).

Gikatilla introduces here a decisive correction to his former assumptions. The knowledge of God is still limited in theological-political terms, since Abraham and Isaac cannot rise beyond a certain point. Yet those who can actually ascend through the Central Pillar are eventually able to access the Crown through a larger set of hermeneutical means: every ornament of every letter in Scripture. In so doing Gikatilla seems to imply that there is a potentially endless access to Crown through Scripture. Yes, this supreme knowledge is indeed exclusive for those who are able to ascend the Central Pillar but it seems that the final access is not limited to a single, special letter (again, the apex of the letter Yod of the Tetragrammaton); on the contrary, any ornament of any letter in Scripture will do. How is then possible to negotiate "secrecy" when every ornament of every letter gives access to God? This is the crucial question to which Gikatilla tries to answer after the revising the last chapter of Saha'arey Tzedek.

For not evident reasons, Gikatilla eventually abandoned the idea of revising the whole text of Sha'arey Tzedek. He rather decided to write a new book, very similar in form and content: Sha'arey Orah ("The Gates of Light"). In the present occasion it is clearly impossible to deal with similarities and differences between these two commentaries on the ten sefirot. Therefore, I will focus on one of the most important congruencies. In the last chapter of Sha'arey Orah, Gikatilla borrows from the revised last chapter of Sha'arey Tzedek the idea that every ornament of every letter in Scripture is connected to Crown and he reports verbatim the very passage mentioned above. Yet, at the same time, Gikatilla introduces also a new notion: a tradition transmitted "mouth to mouth." Gikatilla actually emphasizes in Sha'arey Orah the importance of "orality" while transmitting mystical knowledge. Although Gikatilla is writing a detailed introduction for his anonymous friend, he also warns him three times about the necessity of receiving "oral teaching." The reasons for referring to a tradition that has been transmitted "mouth to mouth" are probably many and simultaneous.

${ }^{17}$ Ephraim Gottlieb, "HaKetah haAkharon shel Sefer Sha'are Tsedek leR. Yoseph Gikatilla," Tarbiz 39 (1970): 359-389, then published in Ephraim Gottlieb, Mehkarim be-Sifrut ha-Kabbalah (Tel Aviv: Hacker, 1976), 59-87. 
On the one hand, the claim to "orality" surely has also the rhetorical effect of emphasizing the value of the written text itself: namely, the very text that is revealing also even more secret traditions that would otherwise be transmissible only orally. Besides, one should also not rule out the less prosaic circumstance that in so doing, Gikatilla could also increase the monetary value of the text that he had presumably been hired to write for his anonymous friend.

On the other hand, Gikatilla seems to expand here the dimension of "orality" that had been mentioned only once in the previous text Sha'arey Tzedek. In so doing Gikatilla seeks one specific purpose: reinstalling a dimension of "secrecy" that could be endangered by assuming that every ornament of every letter in Scripture could provide a decent knowledge of God. Therefore, if the revised last chapter of Sha'arey Tzedek could suggest that not simply every ornament of every letter in Scripture rather that any ornament of any letter in Scripture could be sufficient to understand God, the final chapter of Sha'arey Orah actually corrects this implicit radical "textualism" and introduces the supplementary notion of "orality." Whether every ornament of every letter in Scripture has this latent potentiality of providing access to infinite knowledge, a true kabbalist still has to relay on traditions transmitted "orally," since "orality" still is a necessary step in transmitting mystical knowledge. How shall we then treat these at first contradicting assumptions between "textuality" and "orality"? The simultaneous presence of "orality" and "textualism" in Sha'arey Orah could be justified by referring to the notion of "open esotericism" - recently used by Hartley Lachter to describe the complex intellectual condition of the 13th century Jewish mysticism in Spain. ${ }^{18}$ This notion permits to justify the simultaneous need for providing both a "textual" and an "oral" tradition of mystical principles with respect to their theological-political potentialities.

On the one hand, the $13^{\text {th }}$ century Spanish kabbalists were engaged with the task of providing the necessary means by which any member of a Jewish community could eventually understand Scripture in mystical terms. This would clearly emphasize the dimension of "openness" in the ambivalent notion of "open esotericism."

On the other hand, the $13^{\text {th }}$ century Spanish Kabbalists could share their knowledge to the Jewish masses but would hardly abdicate their socially established privileges as leaders of the Jewish community. Therefore, the dimension of "orality" would have the specific purpose of remarking the theological-political importance of the Rabbinic elite. This would then emphasize the dimension of "secrecy" in the ambivalent notion of "open esotericism." In conclusion, the latest Gikatilla would propose a sort of harmonic association of "textuality" with "orality" but this would imply neither a Christian-like dialectics between "letter" and "spirit" nor any "theological-political reticence" as maintained elsewhere by Leo Strauss. On the contrary Sha'arey Orah is almost candid in admitting the highest election of Israel and its theological-political role in God's plan, with the exception that some secrets still have to be transmitted "orally" only under the supervision of the Rabbinic elite and shall not became matter of simple "textual" interpretation.

It is evident that the Kabbalistic notion of "Scripture" collapses all the two previous ones: the epistemological provided by the Rabbinic notion and the cosmological provided

${ }_{18}$ Hartley Lachter, Kabbalistic Revolutions. Reimagining Judaism in Medieval Spain (New Brunswick: Rutgers University Press, 2014). 
by the Midrashic notion. The Kabbalistic notion of "Scripture" maintains that the ontological connection between God and Scripture justifies the epistemological prominence of Scripture over other disciplines as well as the assumption that Scripture represents the cosmological horizon of reality.

By emphasizing the encyclopaedic notion of "Scripture" and the assumption that there is God "behind" Scripture, the Kabbalist notion of "Scripture" claims for a more or less emphatic "theology of text." More particularly, whereas the former notions would claim that Scripture derives from God and reflects the ordinate structure of cosmos, the Kabbalistic notion of "Scripture" identifies God with the text of Scripture itself, due to an ontological connection between these two.

\section{The post-modern and post-structural notion of "Text"}

When translated into philosophical terms, the notion of "Scripture" is transformed or, better put, is secularized into the notion of "text," yet still maintaining some of the same sacral connotations.

As we have seen, the Kabbalah would account Scripture as a hierophany in its strongest sense: God would actually be present within the text of Scripture itself, due to its hermeneutical, cosmological, and ontological prerogatives.

On the contrary, post-modern and post-structuralist philosophy has proven the limits of this notion of "Scripture" or, better put, its metaphysical presuppositions by addressing its epistemological, cosmological, and ontological assumptions.

For brevity's sake I will refer here only to three important examples: the scholarship of Marc-Alain Ouaknin, the philosophy of Jacques Derrida, and the notion of "plasticity" as an alternative to "writing," "dialectics," "destruction," and "deconstruction" in the French philosopher Catherine Malabou. I refer to these three thinkers for specific reasons: I assume that the former, Ouaknin, deconstructs the Rabbinic notion of "text" and its epistemological presuppositions, whereas the latter, Derrida, deconstructs the Kabbalistic notion of "text" and its ontological presuppositions; finally, Malabou transforms the notion of "textualism" into the notion of "plasticity."

Ouaknin deconstructs the Rabbinic notion of "text" in a very complex way: he applies the mystical experience of Rabbi Nachman of Braslav (who was ordered to burn his mystical texts) back to the Rabbinic notion of "Scripture."19 More specifically, he maintains that the Talmud has also experienced a sort of "self-effacement," especially when Moses broke the Tablets of the Law after learning of the idolatrous manufacture of the golden calf:

\footnotetext{
${ }^{19}$ Rabbi Nachman of Braslav (known also as: Rebbe Nachman of Breslov, Nachman Breslover or Nachman of Uman) (1772-1810) was a leading figure of Russian-speaking Chassidism and the founder of the homonymous Breslov dynasty. As great-grandson of the Baal Shem Tov, Rabbi Nachman offered a singular combination of Jewish mysticism and Talmudic scholarship. Among his four main works, published posthumously by his disciple Reb Noson, particularly prominent are two books that he burnt: Sefer ha-Ganuz ("The Hidden Book") and especially Sefer ha-Nitzraf ("The Burned Book"). His decision to burn his own books has recently led to an interesting comparison being made with Franz Kafka. See Rodger Kamenetz, Burnt Books. Rabbi Nachman of Bratslav and Franz Kafka (New York: Schocken, 2010).
} 
the breaking of the tables is not the destruction of the law; it is on the contrary the gift of the law in the for of its breaking... Moses does not pass on, at first the Law, but its shattering; its impossibility of being an idol, the place of perfection..$^{20}$

In other terms, the breaking of the Tables would somehow consist in an act of "freedom," since the too bulky presence of God within Scripture had literally been effaced by breaking the first Tablets. As far as Ouaknin provides a daring combination of Talmud, Kabbalah, heresy, and post-Structuralism, it is obvious how his vision of intellectual freedom is founded on the inversion of traditional textualism and its epistemological presuppositions. Accordingly, Ouaknin rejects the traditional notion of Scripture as the actual presence of God in the text itself and vouchers for a radical hermeneutics that flirts both with negative mysticism and epistemological nihilism. On the contrary, Derrida has developed the notion of "grammatology" that has deconstructed the traditional notion of "text." On account of a number of philosophical suggestions, Derrida has claimed that "text" would hardly be that "totality" that "it" (the text itself) desires to be - rather a "construct" that is itself exposed to an epistemological failure or scepticism and atheism. As Derrida himself claimed:

Indeed, reduced to its textuality, to its numerous plurivocality, absolutely disseminated, the Kabbalah, for example, evinces a kind of atheism, which, read in a certain way - or just simply read - it has doubtless always carried within it. ${ }^{21}$

Elliot Wolfson has proven the convergence between Derrida and the Kabbalah on account of a number of topics, ${ }^{22}$ such as: circumcision, gift, secrecy, and so on - but especially on account of an assumption that descends from the previous quotation: the "materiality" of being would be "textual" - so that "ontology" and "grammatology" would coincide. As a consequence of this, if we accept Wolfson argument's, the notion of "grammatology" would exactly express the assumption that interpretation never leads to an "original" truth - rather always to a supplementary text that, in turn, would be in need of further interpretation. "Grammatology" would then imitate the Rabbinic notion of "infinite interpretation" with a decisive correction: there would be no God (or any "ideological" substitution for Him) in the text - but the text itself.

In her recent text, Plasticity at the Dusk of Writing: Dialectic, Destruction, Deconstruction, Malabou has proven how the notion of "plasticity" gradually asserts itself following a chain of specific, consequent concepts: "dialectic," "destruction," "deconstruction" and, with the latter, "writing." While advocating a sort of interstitial position between dialectic, destruction and deconstruction, Malabou appears to adopt the notion of "plasticity" as a sort of concrete, substantial, if not "empiric" kind of "textualism" that eventually overcomes the "fratricidal hand-to-hand battle of presence and the absenting of presence, the present and its withdrawal" fought between "destruction" (Heidegger) and "deconstruction" (Derrida). The "presence" of "plasticity" somehow bypasses the issue of

${ }_{20}$ Marc-Alain Ouaknin, The Burnt Book. Reading the Talmud (Princeton: Princeton University Press, 1998$), 300$.

${ }^{21}$ Jacques Derrida, Dissemination (Chicago: University of Chicago Press, 1981), 244.

${ }^{22}$ See for instance, the notable: Elliot Wolfson, "Assaulting the Border. Kabbalistic Traces in the Margins of Derrida," Journal of American Academy of Religion 70, no. 3 (2002): 475-514. 
"presence of a text" - or "textualism" - and relaunches a sort of intermediation that is neither dialectical nor non-dialectical:

to think of plasticity is to think about an imminent disruption, a sudden transformation without any change of ground, a mutation that produces a new form of identity and make the former one explode. ${ }^{23}$

In this perspective, Malabou's notion of "plasticity" appears to transform the notion of "writing" and, with it, the notion of "textualism" into a sort of praxis that fundamentally consists in engraving when not simply carving into a receptive support that is neither fragile under the effects of writing nor impermeable to any sign. This notion of "plasticity" if not this metaphor would then designate both the achievement of "presence" in a "text" and its disruption as sign put unto a malleable - or "plastic" - support. In providing such a form of alterity without transcendence, Malabou's notion of "plasticity" would bring to end the same notion of "textualism," since neither words nor commandments can truly be written much less so "carved" into a support that is ontologically not receptive. Consequently, Malabou would bring the notion of "grammatology" to a sort of "historical materialism" (Historischer Materialismus) embedded into the letter of the "text" but that cannot be "described" into it.

\section{Conclusion}

My assumption is that post-modern philosophy and its textualism should be accounted for as a very peculiar form of "secularization:" the passage from the notion of "Scripture" to the notion of "text."

There is indeed a historical passage from the "religious" notion of "text" that is infinite and all-comprehensive (that is: Scripture) to the more oblique sceptical assumption that a text (any "text") inherently resists to a "theology of letters" because of its "materiality" and its "plasticity," if one wants to refer to Catherine Malabou's vocabulary. Whereas Kabbalah clearly supports the notion of a totalitarian textualism that would provide the absolute auto-sufficiency of the text, Ouaknin and Derrida have claimed, on the contrary, that a referent outside the text may be conceived of a total secularized and sceptics attitude.

Their claims to secularization and scepticism notwithstanding, both the notion of "burnt book" and "grammatology" are occasionally less clear-cut and suggest an ambivalent attitude; on the one hand, a clear rejection of the "ontotheology" 24 with all what this would

\footnotetext{
${ }^{23}$ Catherine Malabou, Plasticity at the Dusk of Writing. Dialectic, Destruction, and Deconstruction (New York: Columbia University Press, 2010), 67.

${ }^{24}$ The term ontotheology was originally derived from the German Ontotheolgie and been used by Immanuel Kant in order to designate a specific branch of "theology" that justifies the existence of God through mere "ontological" conception (Immanuel Kant, Critique of the Pure Reason, A629-A640). Yet in this context the term ontotheology is used according to Heidegger's critique of Kantian metaphysics and especially to Derrida's reception thereof. In poststructural philosophy, the term ontotheolgy conventionally designates a mixture of "theology" and "ontology" by assuming that God would be the Supreme Being and implicitly by evacuating the "ontological question" (Seinsfrage) from the philosophical horizon. With respect of this, "ontotheology" represents a privileged issue in deconstruction, as far as the latter intends to "dismantle" some specific constructions of Western metaphysics. For a recent investigation into the notion of "ontotheology" in French post-structuralist philosophy, see: Joeri Schrijvers, Ontotheological Turnings? The Decentring of the Modern Subject in recent French Phenomenology (Albany: State University of
} 
imply, such as: a form of epistemological scepticism towards an "ultimate truth;" the rejection of traditional monotheism as a form of "patriarchalism;" the rejection of the privilege of "voice," that is the "voice" of the interpreter. On the other hand, both Ouaknin and Derrida would still focus on the book and its letters as well as on the claims of mysteries and revelations, albeit expressed in secularized form. As a consequence of this, the sceptical move against to the traditional notion of deity as transcendental is somehow contradicted by other theological attitudes centred on a spirituality gravitating around a book.

\section{BIBLIOGRAPHY}

Abrams, Daniel. "The Invention of the Zohar as a Book: On the Assumptions and Expectations of the Kabbalists and Modern Scholars." Kabbalah: Journal for the Study of Jewish Mystical Texts 19 (2009): 7-142.

- Kabbalistic Manuscripts and Textual Theory. Methodologies of Textual Scholarship and Editorial Practices in the Study of Jewish Mysticism. Jerusalem: Magnes Press, 2016.

Blickstein, Shlomo. Between Philosophy and Mysticism: A Study of the Philosophical-Qabbalistic Writings of Yosef Gikatila. PhD thesis, New York, 1983.

Calvet, Louis-Jean. Language Wars and Linguistic Politics. Oxford: Oxford University Press, 1998.

Dal Bo, Federico. "Il Teatro del Sapere. Una Interpretazione della Repubblica Platonica," Philo-Logica 5, no. 9 (1996): 91-104.

Daniel, Mano. "A Bibliography of Derrida and Phenomenology." In Derrida and Phenomenology, edited by William R. McKenna and J. Claude Evans, 201-211. Dodrecht: Springer, 1995.

Derrida, Jacques. Dissemination. Chicago: University of Chicago Press, 1981.

Eco, Umberto. Semiotics and the Philosophy of Language. Bloomington: Indiana University Press, 1984.

Fisch, Michael. Jacques Derrida: Bibliographie der Deutschsprachigen Veröffentlichungen in Chronologischer Folge, Geordnet nach den Französischen Erstpublikationen, Erstvorträgen oder Erstabdrucken von 1959 bis 2009. Berlin: Weidler, 2011.

Gottlieb, Ephraim. "HaKetah haAkharon shel Sefer Sha'are Tsedek leR. Yoseph Gikatilla," Tarbiz 39 (1970): 359-389.

- Mehkarim be-Sifrut ha-Kabbalah. Tel Aviv: Hacker, 1976).

Van der Heiden, Gert-Jan. Ontology after Ontotheology. Plurality, Event, and Contingency in Contemporary Philosophy. Pittsburgh: Duquesne University Press, 2014.

Idel, Moshe. Absorbing Perfection. Kabbalah and Interpretation. New Haven: Yale University Press, 2002.

- Kabbalah. New Perspectives. New Haven: Yale University Press, 1990.

Kamenetz, Rodger. Burnt Books. Rabbi Nachman of Bratslav and Franz Kafka. New York: Schocken, 2010.

New York, 2011). See also: Gert-Jan van der Heiden, Ontology after Ontotheology. Plurality, Event, and Contingency in Contemporary Philosophy (Pittsburg: Duquesne University Press, 2014). 
Lachter, Hartley. Kabbalistic Revolutions. Reimagining Judaism in Medieval Spain. New Brunswick: Rutgers University Press, 2014.

Leventure, Albert. "A Bibliography of the French and English Works of Jacques Derrida, 1962-90." Textual Practice 5, no.1 (1991).

Malabou, Catherine. Plasticity at the Dusk of Writing. Dialectic, Destruction, and Deconstruction. New York: Columbia University Press, 2010.

Marmor, Andrei. Law in the Age of Pluralism. Oxford: Oxford University Press, 2007.

McDonald, Lee Martin. The Biblical Canon. Its Origin, Transmission, and Authority. Minneapolis: University of Minnesota Press, 2006.

—. The Canon Debate. Edited by James A. Sanders. Massachusetts: Hendrickson Publishers, 2002.

Ofrat, Gidon. ha- Berit ye-ha-milah shel Z'ak Deridah: 'al Yahadut ke-Petsa', ke-Hotam u-kheAherut. Tel Aviv: ha-Kibutz ha-Meuhad, 2008.

Ouaknin, Marc-Alain. The Burnt Book. Reading the Talmud. Princeton: Princeton University Press, 1998.

Rorty, Richard. Consequences of Pragmatism. Essays, 1972-1980. Minneapolis: University of Minnesota Press, 1982).

- "Nineteenth-Century Idealism and Twentieth-Century Textualism." The Monist 64.2 (1981): 155-174.

Schmitt, Carl. The Concept of the Political. Chicago: University of Chicago Press, 1996.

Scholem, Gershom. Kabbalah. New York: Dorset Press, 1987. . Origins of the Kabbalah. Princeton: Princeton University Press, 1990.

Schorch, Stefen. "Rewritten Bible and the Vocalization of the Biblical Text." In Rewritten Bible after Fifty Years. Text, Terms, or Techniques, edited by J. Zsengellér, 137-152. Leiden: Brill, 2014.

Schrijvers, Joeri. Ontotheological Turnings? The Decentring of the Modern Subject in recent French Phenomenology. Albany: State University of New York, 2011.

Schultz, William R. Jacques Derrida: an Annotated Primary and Secondary Bibliography. New York: Garland, 1992.

Segol, Marla. Word and Image in Medieval Kabbalah. The Texts, Commentaries, and Diagrams of the Sefer Yetsirah. Hampshire: Palsgrave McMillan, 2012.

Tov, Emanuel. Textual Criticism of the Hebrew Bible. Minneapolis: Fortress Press, 1992.

Wolfson, Elliot. "Assaulting the Border. Kabbalistic Traces in the Margins of Derrida." Journal of American Academy of Religion 70, no. 3 (2002): 475-514.

- Giving Beyond the Gift. Apophasis and Overcoming Theomania. New York: Fordham University Press, 2014.

Zellinger, Peter. Jacques Derrida: Bibliographie der Französischen, Deutschen und Englischen Werke. Wien: Turia \& Kant, 2005. 